\title{
STUDI KADAR HEMOGLOBIN PADA PENDERITA TUBERCULOSIS (TBC)
}

\author{
Nurul Ni'ma Aziz ${ }^{1)}$, Hasnah ${ }^{1)}$,Fatmawati ${ }^{1)}$ \\ 1)Politeknik Kesehatan Muhammadiyah Makassar \\ Alamat korenspondensi:enenima03@gmail.com
}

\begin{abstract}
Abstrak
Penelitian ini dilatarbelakangi oleh Tuberculosis yang merupakan masalah kesehatan di seluruh negara yang diakibatkan oleh infeksi Mycobacterium tuberculosis. Penderita TB umumnya disertai dengan kekurangan energi kronis, kekurangan gizi dan mengalamai defisiensi mikronutrien. Penderita TB paru mengalami perubahan metabolisme yang disebabkan sitokin-sitokin pro inflamasi yang disekresi oleh sel-sel imun sebagai respon imun terhadap infeksi bakteri TB. Hal tersebut diduga menjadi penyebab kekurangan energi kronis yang berdampak status gizi yang lebih buruk. Defisiensi asupan makanan mempengaruhi proses eritropoesis yaitu produksi sel darah merah oleh sumsum tulang. Proses eritropoesis tersebut membutuhkan bahan dasar esensial yang beberapa bahan tidak dapat disediakan oleh tubuh. Hemoglobin adalah produk proses eritropoesis yang terbentuk dengan ketersediaan zat besi secara cukup. Penelitian ini bertujuan untuk menentukan gambaran hasil kadar hemoglobin pada penderita tuberculosis sebelum pengobatan. Jenis penelitian ini bersifat deskriptif observasional dengan melakukan pemeriksaan kadar Haemoglobin menggunakan Sysmex KX-21 dengan menggunakan metode Resistensi Elektronik (Impedans). Sampel yang diperiksa berupa plasma penderita TB sebanyak 20 sampel dengan teknik pengambilan sampel yaitu purposive sampling. Berdasarkan hasil penelitian menunjukkan bahwa dari 20 sampel diperoleh 8 orang (40\%) menunjukkan kadar hemoglobin yang rendah, 12 orang (60\%) menunjukkan kadar hemoglobin yang normal. Sehingga dapat disimpulkan bahwa infeksi TB beresiko mengalami penurunan kadar haemoglobin.
\end{abstract}

Kata Kunci: Tuberculosis, Haemoglobin, Resistensi Elektronik (Impedans)

\section{Study of Levels of Hemoglobin In Tuberculosis Patients}

\begin{abstract}
This research is motivated by Tuberculosis which is a health problem in all countries caused by infection with Mycobacterium tuberculosis. TB sufferers are generally accompanied by chronic energy deficiency, malnutrition and experience micronutrient deficiencies. Pulmonary TB sufferers undergo metabolic changes caused by pro-inflammatory cytokines secreted by immune cells as an immune response to TB bacterial infections. This is thought to be the cause of chronic energy shortages that have an impact on poorer nutritional status. Deficiency of food intake affects the process of erythropoesis, namely the production of red blood cells by the bone marrow. The erythropoesis process requires an essential base material which some body cannot provide. Hemoglobin is a product of the erythropoesis process that is formed with sufficient iron availability. This study aims to determine the picture of hemoglobin levels in tuberculosis patients before treatment. This type of research is descriptive observational by examining hemoglobin levels using Sysmex KX-21 using the Electronic Resistance (Impedance) method. Samples examined were in the form of plasma TB patients as many as 20 samples with a sampling technique that was purposive sampling. Based on the results of the study showed that from 20 samples obtained 8 people (40\%) showed low hemoglobin levels, 12 people (60\%) showed normal hemoglobin levels. So it can be concluded that TB infection is at risk of experiencing a decrease in hemoglobin levels.
\end{abstract}

Keywords: Tuberculosis, Hemoglobin, Electronic Resistance (Impedance)

\section{PENDAHULUAN}

Penyakit Tuberkulosis (TB) adalah penyakit infeksi kronis yang masih tetap merupakan masalah kesehatan dunia termasuk Indonesia. World Health Organization (WHO) melaporkan tahun 2005 dalam Global Tuberculosis Control menyatakan terdapat 22 negara 
dikategorikan sebagai high-burden countries dan Indonesia termasuk peringkat ketiga setelah India dan China. Penderita TB paru di Indonesia umumnya merupakan kelompok usia produktif dan menderita kekurangan energi kronis, kekurangan gizi serta mengalamai defisiensi mikronutrien. Penderita TB paru mengalami perubahan metabolisme yang disebabkan sitokin-sitokin pro inflamasi yang disekresi oleh sel-sel imun sebagai respon imun terhadap infeksi bakteri TB. $\mathrm{Hal}$ tersebut diduga menjadi penyebab kekurangan energi kronis yang berdampak status gizi yang lebih buruk. Sehingga penderita TB lebih beresiko mengalami malnutrisi. Defisiensi asupan makanan mempengaruhi proses eritropoesis yaitu produksi sel darah merah oleh sumsum tulang. Proses eritropoesis tersebut membutuhkan bahan dasar esensial yang beberapa bahan tidak dapat disediakan oleh tubuh. Hemoglobin adalah produk proses eritropoesis yang terbentuk dengan ketersediaan zat besi secara cukup. (Lauralee Sherwood, 2011).

Kadar Haemoglobin yang normal bagi pria umumnya sekitar 13,8 sampai 17,2 g/dL. Sedangkan untuk wanita adalah 12,1 sampai $15,1 \mathrm{~g} / \mathrm{dL}$. (WHO, 2011)

\section{METODE PENELITIAN}

\section{Alat dan Bahan}

Alat yang digunakan adalah darah plasma, tabung EDTA, rak tabung dan Sysme

KX-21. Bahan yang digunakan adalah

EDTA sebagai anti koagulan.

\section{Prosedur Kerja}

Disiapkan 20 tabung EDTA untuk menampung plasma darah penderita. Kemudian masing-masing diisi darah penderita sebanyak $2 \mathrm{cc}$ dan selanjutnya tekan tombol aspirate pada alat Sysmes KX-21 pada masing-masing sampel. Prinsip pemeriksaan haemoglobin yaitu dengan penambahan reagen lyse stromatolyser-WH, maka haemoglobin dari sampel akan bereaksi membentuk senyawa siantmethaemoglobin / methaemoglobin. Larutan tersebut di ukur dengan panjang gelombang $555 \mathrm{~nm}$.

\section{Interpretasi Hasil}

Nilai normal Haemoglobin pada pria umumnya sekitar 13,8 sampai 17,2 g/dL. Sedangkan untuk wanita adalah 12,1 sampai $15,1 \mathrm{~g} / \mathrm{dL}$

\section{Analisis Data}

Analisis data disajikan dalam bentuk tabel untuk melihat gambaran kadar haemoglobin penderita TB dan diolah untuk menyajikan dalam persentase.

\section{HASIL DAN PEMBAHASAN}

Tabel 1. HasilPemeriksaanKadar Haemoglobin pada Penderita TB sebelum pengobatan Menggunakan Metode Resistensi Elektronik(Impedans)

\begin{tabular}{ccccc}
\hline \multirow{2}{*}{$\begin{array}{c}\text { Kode } \\
\text { Sampel }\end{array}$} & \multicolumn{2}{c}{$\begin{array}{c}\text { Jenis } \\
\text { Kelamin }\end{array}$} & $\begin{array}{c}\text { Kadar Hemoglobin } \\
\text { (g/dl) }\end{array}$ & KET \\
\cline { 2 - 3 } 1 & L & P & & \\
\hline 2 & - & $\sqrt{ }$ & 12,4 & Normal \\
3 & $\sqrt{ }$ & - & 13,0 & Normal \\
4 & - & $\sqrt{ }$ & 14,5 & Normal \\
5 & - & $\sqrt{ }$ & 11,1 & Normal \\
6 & - & $\sqrt{ }$ & 15,1 & Normal \\
7 & - & $\sqrt{ }$ & 14,7 & Normal \\
8 & $\sqrt{ }$ & - & 11,9 & Normal \\
9 & - & $\sqrt{ }$ & 12,9 & Menurun \\
10 & - & $\sqrt{ }$ & 12,5 & Normal \\
11 & - & $\sqrt{ }$ & 10,7 & Normal \\
12 & $\sqrt{ }$ & - & 10,6 & Menurun \\
13 & $\sqrt{ }$ & - & 10,3 & Menurun \\
& & & & Menurun \\
\hline
\end{tabular}




\begin{tabular}{ccccc}
\hline 14 & - & $\sqrt{ }$ & 9,6 & Menurun \\
15 & $\sqrt{ }$ & - & 11,2 & Normal \\
16 & $\sqrt{ }$ & - & 12,4 & Normal \\
17 & $\sqrt{ }$ & - & 9,0 & Menurun \\
18 & - & $\sqrt{ }$ & 10,8 & Menurun \\
19 & $\sqrt{ }$ & - & 11,3 & Normal \\
20 & - & $\sqrt{ }$ & 10,2 & Menurun \\
\hline
\end{tabular}

Tabel 2. Persentase kadar hemoglobin penderita TB sebelum pengobatan

\begin{tabular}{cccc}
\hline \multicolumn{2}{c}{ Hasil } & \multicolumn{2}{c}{ Persentase (\%) } \\
Normal & Menurun & Normal & Menurun \\
\hline 12 & 8 & 60 & 40 \\
\hline 20 sampel & \multicolumn{2}{c}{$\mathbf{1 0 0 \%}$} \\
\hline
\end{tabular}

Penelitian ini dilakukan secara cerminan perubahan patofisiologi yang observasi laboratorik yang bertujuan untuk mengetahui kadar hemoglobin penderita TB sebelum pengobatan. Hasil penelitian didapatkan penderita TB dengan nilai hemoglobin yang kurang dari normal 4 orang laki-laki dan 4 orang perempuan dari 20 sampel yang digunakan atau sekitar $40 \%$ dari jumlah keseluruhan sampel. Hal ini menunjukkan bahwa anemia bisa menyerang penderita tuberkulosis baik pada perempuan maupun laki-laki.Ke-8 penderita ini adalah penderita baru yang datang berobat ke RSUD.Labuang Baji dengan keluhan mengalami batuk darah kurang lebih $1-2$ bulan dan hasil pemeriksaan sputumnya +3 . Sebanyak 12 penderita $(60 \%)$ penderita lainnya yang kadar hemoglobinnya masih dalam batas normal dengan uraian 4 orang penderita baru dengan batuk darah selama 1 minggu dengan hasil pemeriksaan sputum +1 dan 8 orang lainnya adalah penderita baru dengan tanpa disertai batuk darah tetapi hasil pemeriksaan sputumnya +2 dan +3 .

Penurunan kadar hemoglobin dan jumlah eritrosit dapat menyebabkan anemia, hal yg disebabkan oleh adanya proses infeksi tuberkulosis itu sendiri atau kelainan dasar hematologis yang sudah ada sebelumnya. Menurut defenisi, anemia adalah berkurangnya hingga dibawah nilai normal jumlah sel darah merah, kuantitas hemoglobin dan volume hematoktrit per $100 \mathrm{ml}$ darah.Dengan demikian anemia bukan suatu diagnosis melainkan suatu mendasar dan diuraikan melalui anamnesis yang seksama, pemeriksaan fisik dan konfirmasi laboratorium.Karena jumlah efektif sel darah merah berkurang, maka pengiriman oksigen kejaringan menurun.Kehilangan darah yang mendadak (30\% atau lebih), seperti pada pendarahan, mengakibatkan gejala keringat dingin, napas pendek hipovolemia dan hipoksemia termasuk kegelisahan.Salah satu dari tanda yang paling sering dikaitkan dengan anemia pucat.Keadaan ini diakibatkan berkurangnya jumlah volume darah, berkurangnya hemoglobin. Pada penderita tuberkulosis paru apabila terpapar dengan bakteri penyebabnya penyakit memperlihatkan tanda batuk berdahak lebih dari dua minggu, batuk mengeluarkan darah atau pernah mengeluarkan darah, dada terasa sakit atau nyeri dan terasa sesak pada waktu bernapas(Price\& Wilson,2006). Kelainan - kelainan hematologis tersebut merupakan salah satu cara pemantuauan aktivitas penyakit serta pemeriksaan penunjang untuk menilai respon pengobatan pada penderita tuberkulosis.

\section{KESIMPULAN}

Berdasarkan hasil penelitian didapatkan penderita TB dengan nilai hemoglobin yang kurang dari normal sebanyak 8 orang dari 20 sampel yang digunakan atau sekitar 40\%. Sebanyak 12 
penderita $(60 \%)$ penderita lainnya yang kadar hemoglobinnya masih dalam batas normal. Sehingga dapat disimpulkan bahwa terjadi penurunan kadar haemoglobin pada penderita TB yang akan beresiko menyebabkan anemia.

\section{DAFTAR PUSTAKA}

CV. Krista Lab. Panduan Operasional Kerja Sysmex KX-21.

Hiswani, 2004. Tuberculosis Merupakan Penyakit Infeksi Yang Masih Menjadi Masalah Kesehatan Masyarakat. Fakultas Kesehatan Masyarakat. Universitas Sumatera Utara, Medan.

Lay BW, 1994. Analisa Mikroba di laboratorium. Raja Grafindo Persada: Jakarta.

Lumb R, Yamin G \& Bastian I, 2004. Diagnosis Tuberkulosa Secara
Laboratorium

dengan

Pemeriksaan

Mikroskopis

Dahak. Institute of Medical and

Veterinary Sciense: Australia.

Mc.Pherson \& Sacher, 2004. Tinjauan

Klinis Hasil Pemeriksaan

Laboratorium Ed.11. EGC:

Jakarta.

Oehadian A, 2003. Aspek Hematologi

Tuberkulosis. FK-UNPAD: Bandung.

Ryan \& Ray, 2004, Sherries Madical Microbiology an Introduction to Infectious Disease $-4^{\text {th }}$ edition. International Edition.

Sandjaja, 1995. Isolasi dan Identifikasi Mikobakteria. Widya medika: Jakarta.

Simmons. A, 1989, Hematology " A Combined Theoretical \& Technical Approach", W.B. Saunders Company. 